Available online on 15.03.2019 at http://ujpr.org
Universal Journal of Pharmaceutical Research
An International Peer Reviewed Journal
Open access to Pharmaceutical research

\title{
STUDY ON FRESH LEAF AQUEOUS EXTRACT OF FLACOURTIA INDICA FOR HEPATOPROTECTIVE, ANTI-ANEMIC AND HYPOGLYCEMIC ABILITIES IN $\mathrm{CCl}_{4}$ INDUCED HEPATOTOXICITY IN ALBINO WISTAR RATS Idoko A* (D) Ufedo-Enyo G. Emmanuel \\ Department of Biochemistry, Faculty of Natural Sciences, Caritas University, Amorji-Nike, P.M.B. 01784, Enugu, Nigeria.
}

\section{ABSTRACT}

Objective: Hepatic injury and its associated conditions have been reportedly shown to be managed through herbal remedies. In this study, investigation of the fresh leaf aqueous extract of Flacourtia indica (of the family of Salicaceae) as hypoglycemic, antianemic and hepatoprotective agent in albino wistar rats induced $\mathrm{CCl}_{4}$ hepatotocxicity was done.

Methods: Fifteen rats of either sex, weighing 175-295g, divided into five groups (I-V) of three rats each, were used. Group-I is negative control, II-positive control and III -V test groups. Groups II-V were induced $200 \mathrm{mg} / \mathrm{Kg} /$ bodyweight $\mathrm{CCl}_{4}$, for 3 -days, for hepatic injury and anemia. Groups III-V were respectively treated orally with 400,600 and $800 \mathrm{mg} / \mathrm{Kg} / \mathrm{bodyweight}$ of fresh leaf aqueous extracts (FLAE) of Flacourtia indica, for 7-days.

Results: Activities of alanine aminotransferase, aspartate aminotransferase, alkaline phosphatase, concentrations of bilirubin, albumin, total protein, blood glucose and packed cell volume (PCV) and hemoglobin were assayed. Results after induction showed significant $(p<0.05)$ decrease in heamoglobin and PCV, significant $(p<0.05)$ increase in the liver function enzymes and blood glucose compared with results of liver function enzyme and blood glucose having significant $(p<0.05)$ decrease, and significant $(p<0.05)$ increase of PCV and hemoglobin after treatment with FLAE of Flacourtia indica. Body weight of rats induced $\mathrm{CCl}_{4}$ was found to increase with FLAE of Flacourtia indica treatment.

Conclusion: It may be concluded that the potentials exhibited by FLAE of Flacourtia indica to manage hyperglycaemia, hepatic injury and anemia induced by $\mathrm{CCl}_{4}$ are associated with its antioxidant activity and the presence of phytochemicals, minerals and nutrients value.

Keywords: Anti-anemic, Flacourtia indica, hepatoprotective, hepato-function, hypoglycemia, toxicity.

Article Info: Received 4 January 2019; Revised 5 February; Accepted 6 March, Available online 15 March 2019

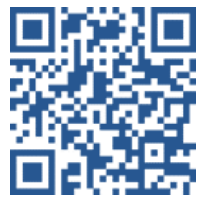

Cite this article-

Idoko A, Ufedo-Enyo G. Emmanuel. Study on fresh leaf aqueous extract of flacourtia indica for hepatoprotective, anti-anemic and hypoglycemic abilities in $\mathrm{CCl}_{4}$ induced hepatotoxicity in albino wistar rats. Universal Journal of Pharmaceutical Research 2019; 4(1): 17-22.

DOI: https://doi.org/10.22270/ujpr.v4i1.234

Address for Correspondence:

Idoko A, Department of Biochemistry, Faculty of Natural Sciences, Caritas University, Amorji - Nike, P.M.B. 01784, Enugu, Nigeria. Phone: +2348032354823, E-mail: idokoalexander1 @ gmail.com

\section{INTRODUCTION}

Plants have been largely used in the quest of managing health challenges as alternative of nature's providence. Traditional medicine practice is an age long practice common in developing countries ${ }^{1}$. Several bioactive compounds in plants are known with their antioxidant and scavenging abilities ${ }^{2}$. Phytochemicals are chemicals in plants with no nutritive value but highly effective in disease prevention and protection when consumed. Most of these bioactive plants' compounds have been implicated in the treatment, management and prevention of ailments. Several studies have demonstrated the use of plants' extracts as hepatoprotective and gluco-stabilizer in Albino wistar rats induced aluminium chloride hepatic toxicity ${ }^{3}$ and $^{4}$ reported various methods of extraction, isolation, identification and purification of bioactive compounds in plants. Flacourtia indica's leaf, stem bark, fruits and root like other plants, is not exempted from these beneficial characteristics. These have been shown to possess biological, medicinal and pharmacological potentials in the prevention and treatment of hepatic disease $^{3}$, cardiovascular diseases, cancer $^{5}$, diabetes ${ }^{6}$, bacterial infection ${ }^{1}$, and other conditions like anemia hyperglycemia and hypercholesterolemia ${ }^{7,8}$. Various researchers have demonstrated that plants are rich sources of antioxidant vitamins such as vitamins $\mathrm{A}, \mathrm{C}$ and $\mathrm{E}^{4}$, minerals such as $\mathrm{Fe}, \mathrm{Mg}, \mathrm{Mn}, \mathrm{N}, \mathrm{P}, \mathrm{Ca}, \mathrm{Na}$ and $\mathrm{K}^{9}$ and phytochemicals such as phenolics (tannins, flavonoids), carotenoids, anthocyanins, coumarin glycosides $^{1}$. The liver is an organ with multiple functions. It is involved in circulation of blood, plays 
major role in metabolic reactions, seen in conversion of excess blood glucose to glycogen, carries out detoxification by secretion of bile, involved in production of blood clotting factor by production of fibrinogen, heparin and prothrombin ${ }^{10,11}$. Hepatic diseases pose a universal concern to Humans and other animals, contributing a large cause of mortality and morbidity. These include fatty liver, cirrhosis; hepatitis (A, B, C, D and E), drug/chemical induced hepatic injury, hepatic cancer and alcohol induced hepatic injury ${ }^{11}$. Chemical/drug induced liver toxicity is reported to be the paramount cause of hepatotoxicity. This has been linked to life style, abuse and misuse of drug, occupational, laboratory and industrial exposure to substances and chemicals like carbon tetrachloride, aluminum chloride, alcohol etc ${ }^{10}$. The mechanism through which carbon tetrachloride $\mathrm{CCl}_{4}$ and these other chemical substances exert liver damage is understood to be linked to production of reactive oxygen species. This result in lipid peroxidation of liver tissues as a consequence of the high put of free radicals generated which subdues the liver's defense system, degenerating to inflammation, hepatic apoptosis, liver cirrhosis and fibrosis ${ }^{12,13}$.

Anemia sets in due to lack of adequate and healthy red blood cells (RBC) and hemoglobin, the oxygen binding component of the blood. Anemia is a condition that is commonly affected by infants, child bearing age women/pregnant women, the young and the elderly ${ }^{14}$. Different types of anemia arise from their causes. Anemia is considered to be caused by abnormal RBC production (iron deficiency anemia, vitamin deficiency anemia, aplastic anemia thalasemia etc), destruction of red blood cell (sickle cell anemia ${ }^{15}$. Anemia has been reported to be induced by several chemical substances such as $\mathrm{AlCl}_{3}$ and phenylhydrazine ${ }^{14,16}$, reported the prevalence of anemia among the elderly with value of hemoglobin $\mathrm{Hb}<12 \mathrm{~g} / \mathrm{dl}$ in women and $\mathrm{Hb}<13 \mathrm{~g} / \mathrm{dL}$ in men.

This study was carried out to evaluate the potential of fresh leaf aqueous extracts (FLAE) of $F$. indica as a hepatoprotective, anti-anemic and hypoglycemic agent in $\mathrm{CCl}_{4}$ induced hepatic injury in Albino wistar rats.

\section{MATERIALS AND METHODS}

\section{Collection and Preparation of Plant Samples}

Fresh leaf materials of $F$. indica (Governor's plum) were collected from around staff quarter of Caritas University, Amorji-Nike, Enugu state, Nigeria. The required plant leaf was authenticated and a voucher number of PSB/109-12.A was given by Mr. Okafor, C.U., a botanist in plant tissue culture and biotechnology department, Faculty of Biological Science, University of Nigeria, Nsukka. The aqueous plant extracts were prepared selecting fresh leaf aerial part, weighed and squeezed in a bowl of containing water and filtered and filtrate was used for oral treatment. The volumes of the extracts to be administered were calculated according to the body weight of the rats.

\section{Collection and Preparation of Blood Sample}

Three milliliter $(3 \mathrm{ml})$ of blood was collected from the rats by capillary pressure insertion into the side of the eye using capillary tubes into a plain bottle, for the collection of serum used for biochemical assay (liver function test) and about $3 \mathrm{mls}$ collected in an EDTA sample bottle for hematological assay (PCV and hemoglobin). The samples in bottles were stored at room temperature.

\section{Study Animals}

Albino Wistar rats of $175-294 \mathrm{~g}$ weight, of either sex were obtained from university of Nigeria Nsukka. Animals were housed at an ambient temperature and relative humidity in the animals' house of department of Biochemistry, natural sciences, Caritas University, Amorji-Nike Enugu. The rats were allowed to acclimatize for one week prior to the experiment and had access to standardized pelletized finisher feed and clean water within the period of the acclimatization. The principle of laboratory animals' care and ethical guidelines for investigation of experimental pain in conscious animals were followed respectively ${ }^{17,18}$.

\section{Design and Animal Grouping}

A total of fifteen (15) Wistar albino rats, divided into five groups (Groups I-V) of three rats each was used for this study.

Group I: Negative control consist of 3 rats, no carbon tetrachloride $\mathrm{CCl}_{4}$ and FLAE of $F$. indica were administered.

Group II: Test control (positive control) consist of 3 rats, were administered orally with $200 \mathrm{mg} / \mathrm{Kg}$ / body weight $\mathrm{CCl}_{4}$ without FLAE of $\mathrm{F}$. indica.

Group III: Consist of 3 rats, administered orally with $200 \mathrm{mg} / \mathrm{Kg} /$ body weight $\mathrm{CCl}_{4}$ and $400 \mathrm{mg} / \mathrm{kg} /$ body weight FLAE of $F$. indica.

Group IV: $\quad$ Consist of 3 rats, administered orally with $200 \mathrm{mg} / \mathrm{Kg} /$ body weight $\mathrm{CCl}_{4}$ and $600 \mathrm{mg} / \mathrm{kg} /$ body weight FLAE of $F$. indica.

Group V: $\quad$ Consist of 3 rats, administered orally with $200 \mathrm{mg} / \mathrm{Kg} /$ body weight $\mathrm{CCl}_{4}$ and $800 \mathrm{mg} / \mathrm{kg} /$ body weight FLAE of $F$. indica.

At the end of induction (three days), blood sample was collected from each group for biochemical and hematological assays before treatment with FLAE of $F$. indica. After treatment with FLAE of Flacourtia indica for seven days, blood sample was also collected for biochemical and hematological assays.

\section{Induction of Liver Injury and Anemia}

Rats of groups II-V were induced with liver injury and anemia by single oral administration with $200 \mathrm{mg} / \mathrm{kg}$ body weight of $\mathrm{CCl}_{4}$ respectively. A confirmatory test was carried out after induction of anemia by assaying the plasma hemoglobin percentage to show that the rats were anemic.

\section{Liver Function Assay}

After collection of blood sample from rats, serum was collected by clot retraction. Serum ALT, AST, ALP, Albumin, Total protein and Bilirubin were assayed by the standard method as described by ${ }^{19}$ with the use of kits from Randox Laboratories Ltd, 55 Diamond Road, Crumlin, country Antrim, BT29 4QY, United Kingdom. 


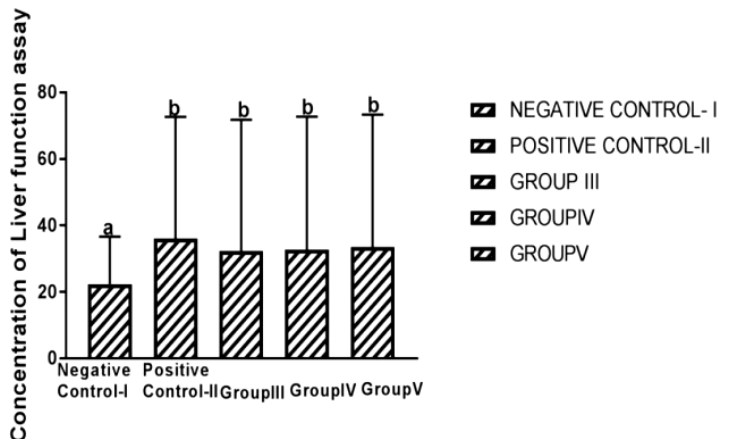

Figure 1: Liver function test after induction with $200 \mathrm{mg} / \mathrm{kg}$ body weight $\mathrm{CCl}_{4}$.

Letters $\mathrm{a}$ and $\mathrm{b}$ indicates significant difference $(P<0.05)$ when group I was compared with groups II, III, IV and V, respectively after $\mathrm{CCl}_{4}$ induction of liver damage to rats in these groups. Graphs with same letters are not significantly $(P<0.05)$ different

\section{Hematological Assay}

The Haemoglobin $(\mathrm{Hb})$ and packed Cell Volume (PCV) values were determined by standard method as described in a previous study ${ }^{20}$ using hematocrite and Mindray Haematology Analyser (Mindray BC-2300, Guangzhou Shihai Medical Equipment Co., Ltd, China).

\section{Chemicals}

All chemicals used were pure and of analytical grade. Liver function enzymes assay reagents for Bilirubin (BIL), Alanine Aminotransferase (ALT), Aspartate Aminotransferase (AST), Albumin (ALB), Total Protein (TP) and Alkaline phosphatase (ALP) employed kits obtained from Randox Laboratories Ltd, 55 Diamond Road, crumlin, country Antrim, BT29 4 QY, United Kingdom. Aluminium trichloride $\mathrm{AlCl}_{3}$ was purchased from BDH Laboratories/Chemicals Ltd, Poole, England.

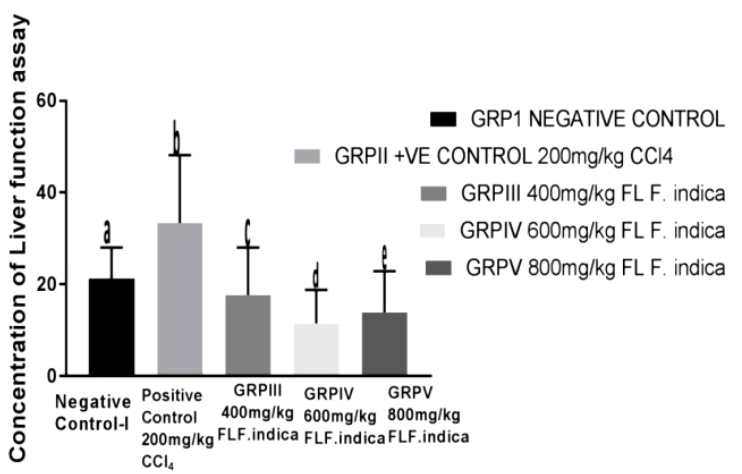

Figure 2: Liver function Assay for $\mathbf{C C l}_{4}$ induced rats treated with fresh leaf aqueous extract of $F$. indica.

FLF. indica $=$ fresh leaf of $F$. indica. Letters a, b, c, d and e indicates significant difference $(P<0.05)$ when group II was compared with groups I, III, IV and V, respectively for $400 \mathrm{mg} / \mathrm{kg}, 600 \mathrm{mg} / \mathrm{kg}$ and $800 \mathrm{mg} / \mathrm{kg}$ FLAE $F$. indica treated groups.

\section{Statistical Analysis}

Results were expressed as mean \pm standard deviation and analyzed using one-way ANOVA (analysis of variance), $p$ value $(<0.05)$ was considered significant. A component of graph pad instat 3 software version
3.05 and graphpad prism version 7.04 by graph pad Inc. was employed ${ }^{21}$.

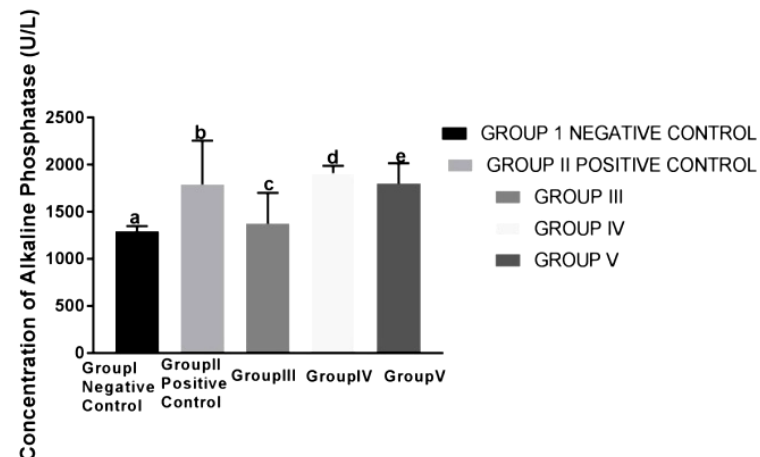

Figure 3: Alkaline phosphatase level of $\mathrm{CCl}_{4}$ induced rat's liver damage.

Letters a, b, c, d and e indicates significant difference $(P<0.05)$ when group I was compared with groups II, III, IV and V, respectively after $\mathrm{CCl}_{4}$

\section{RESULTS}

Table 1 shows the liver function parameters of rats after induction with $200 \mathrm{mg} \mathrm{CCl}_{4}$, for liver injury. There was an observed significant $(p<0.05)$ increase in TP, ALB, BIL, ALP, ALT and AST of group I (negative control) compared to group II (positive control) and test groups (III, IV and V). Table 2 shows liver function assay of rats administered various doses $(400 \mathrm{mg} / \mathrm{kg}, 600 \mathrm{mg} / \mathrm{kg}$ and $800 \mathrm{mg} / \mathrm{kg}$ ) of Fresh Leaf Aqueous Extract (FLAE) of $F$. indica for seven (7) days. A significant $(p<0.05)$ increase was observed in all parameters assayed in the test groups (III, IV and V) compared to group II (test control) and group I (negative control). The packed cell volume (PCV) and hemoglobin of rats after induction with $\mathrm{CCl}_{4}$ and after treatment with Fresh Leaf Aqueous Extract (FLAE) of $F$. indica for seven (7) days is shown in table 3. The result shows a significant $(p<0.05)$ increase in PCV and hemoglobin after treatment with FLAE of $F$. indica compared to after induction with $\mathrm{CCl}_{4}$.

Blood glucose concentration of rats after induction with $\mathrm{CCl}_{4}$ and after Treatment with Fresh Leaf Aqueous Extract (FLAE) of $F$. indica for seven (7) days is shown in Table 4. After FLAE $F$. indica was administered, to test groups (III, IV and V), the blood glucose concentrations of test groups were observed to decrease significantly $(p<0.05)$ compared to after induction with $\mathrm{CCl}_{4}$ and thus acerbating induced hypoglycemia. The body weights of rats are shown in Table 5 at acclimatization, at induction with $\mathrm{CCl}_{4}$ and at treatment with FLAE of $F$. indica. There was significant $(p<0.05)$ decrease in body weight of at induction and significant increase in body weight after treatment with FLAE of $F$. indica, which may be indicative of recovery from anemia. The results show significantly higher $(P<0.05)$ level of group II rats (positive control) compared to group I (negative control), group III $(400 \mathrm{mg} / \mathrm{kg} \mathrm{FLF}$ indica), group IV (600mg/kg FLF. indica) and group V (800mg/kg FLF indica). 
Table 1: Liver function test of rats after induction with $200 \mathrm{mg} / \mathrm{kg} \mathrm{CCl} 4$ body weight of rats.

\begin{tabular}{|c|c|c|c|c|c|c|}
\hline Group & $\mathrm{TP}(\mathrm{g} / \mathrm{dl})$ & $\operatorname{ALB}(g / d l)$ & BIL(mg/dl) & $\operatorname{ALP}(\mathrm{U} / \mathrm{L})$ & $\operatorname{ALT}(\mathbf{U} / \mathrm{L})$ & $\operatorname{AST}(\mathrm{U} / \mathrm{L})$ \\
\hline I & $10.70 \pm 7.11^{\mathrm{abcd}}$ & $4.58 \pm 3.02^{\mathrm{abcd}}$ & $12.88 \pm 0.77^{\mathrm{abcd}}$ & $1381.67 \pm 71.12^{\mathrm{abcd}}$ & $38.7 \pm 5.33^{\mathrm{abcd}}$ & $41.00 \pm 6.44^{\mathrm{abcd}}$ \\
\hline II & $7.49 \pm 5.48^{a}$ & $6.56 \pm 7.13^{\mathrm{a}}$ & $9.49 \pm 1.02^{\mathrm{a}}$ & $2612.00 \pm 36.49^{a}$ & $77.04 \pm 2.34^{\mathrm{a}}$ & $76.8 \pm 4.33^{\mathrm{a}}$ \\
\hline III & $2.58 \pm 0.95^{\mathrm{b}}$ & $3.72 \pm 0.23^{b}$ & $3.38 \pm 0.59^{\mathrm{b}}$ & $1453.14 \pm 419.60^{b}$ & $68.00 \pm 24.37^{\mathrm{b}}$ & $75.00 \pm 10.36^{\mathrm{b}}$ \\
\hline IV & $3.26 \pm 0.49^{c}$ & $3.29 \pm 0.62^{c}$ & $4.09 \pm 0.70^{c}$ & $1927.81 \pm 99.46^{c}$ & $79.50 \pm 20.51^{\mathrm{c}}$ & $78.00 \pm 15.56^{c}$ \\
\hline V & $4.23 \pm 1.78^{\mathrm{d}}$ & $3.75 \pm 0.04^{\mathrm{d}}$ & $4.11 \pm 1.39^{\mathrm{d}}$ & $1712.58 \pm 212.73^{\mathrm{d}}$ & $79.50 \pm 20.51^{\mathrm{d}}$ & $71.50 \pm 6.36^{\mathrm{d}}$ \\
\hline
\end{tabular}

Table 2: Liver function assay of Rats after Treatment with 400,600 and $800 \mathrm{mg} / \mathrm{kg} / \mathrm{body}$ weight of Fresh Leaf Aqueous Extract (FLAE) of $F$. indica.

\begin{tabular}{lcccccc}
\hline Group & $\mathbf{T P}(\mathbf{g} / \mathbf{d l})$ & $\mathbf{A L B}(\mathbf{g} / \mathbf{d l})$ & $\mathbf{B I L}(\mathbf{m g} / \mathbf{d l})$ & $\mathbf{A L P}(\mathbf{U} / \mathbf{L})$ & $\mathbf{A L T}(\mathbf{U} / \mathbf{L})$ & $\mathbf{A S T}(\mathbf{U} / \mathbf{L})$ \\
\hline I & $10.07 \pm 10.82^{\mathrm{abc}}$ & $4.73 \pm 1.22^{\mathrm{a}}$ & $8.98 \pm 1.01^{\mathrm{ab}}$ & $1701.01 \pm 173.23^{\mathrm{abc}}$ & $34.01 \pm 7.33^{\mathrm{abc}}$ & $35.02 \pm 7.24^{\mathrm{abc}}$ \\
II & $6.98 \pm 7.63^{\mathrm{a}}$ & $4.52 \pm 3.11$ & $9.19 \pm 0.12^{\mathrm{a}}$ & $2034.01 \pm 84.12^{\mathrm{a}}$ & $67.00 \pm 2.08^{\mathrm{a}}$ & $72.19 \pm 7.12^{\mathrm{a}}$ \\
III & $2.25 \pm 1.88^{\mathrm{b}}$ & $2.34 \pm 0.97^{\mathrm{a}}$ & $1.54 \pm 0.90$ & $1003.85 \pm 134.52^{\mathrm{b}}$ & $14.33 \pm 9.01^{\mathrm{b}}$ & $59.50 \pm 0.71^{\mathrm{b}}$ \\
IV & $2.75 \pm 0.45^{\mathrm{c}}$ & $1.38 \pm 0.58$ & $2.15 \pm 2.14^{\mathrm{b}}$ & $1565.34 \pm 550.95^{\mathrm{c}}$ & $8.33 \pm 4.04^{\mathrm{c}}$ & $40.33 \pm 2.52^{\mathrm{c}}$ \\
V & $2.26 \pm 0.89$ & $0.46 \pm 0.11$ & $0.51 \pm 0.33$ & $992.22 \pm 68.31$ & $15.67 \pm 4.04$ & $48.33 \pm 9.87$
\end{tabular}

Results are mean \pm standard deviation, Values in the same column bearing similar superscripts are significantly different at $P<0.05$. (n=3). Key: I: Negative Control Group, II: positive control and III, IV and V: Test groups, FLAE: Fresh Leaf Aqueous Extract, TP: Total Protein, ALB: Albumin, BIL: Bilirubin, ALP: Alkaline Phosphatase, ALT: Alanine Transaminase, AST: Aspartate Transaminase.

Table 3: Packed Cell Volume and Hemoglobin of rats after induction with $\mathrm{CCl}_{4}$ and after treatment with FLAE of $\boldsymbol{F}$. indica.

\begin{tabular}{lcccc}
\hline Group & \multicolumn{2}{c}{ After Induction } & \multicolumn{2}{c}{ After Treatment } \\
\hline & PCV & Haemoglobin & PCV & Haemoglobin \\
\hline I & $27.36 \pm 0.69^{\mathrm{a}}$ & $10.00 \pm 4.56^{\mathrm{u}}$ & $39.89 \pm 2.09^{\mathrm{a}}$ & $16.03 \pm 2.05^{\mathrm{u}}$ \\
II & $34.54 \pm 7.15^{\mathrm{b}}$ & $10.78 \pm 2.84^{\mathrm{v}}$ & $49.87 \pm 15.09^{\mathrm{b}}$ & $20.67 \pm 8.15^{\mathrm{v}}$ \\
& & & & \\
III & $31.67 \pm 2.89^{\mathrm{c}}$ & $10.56 \pm 0.96^{\mathrm{w}}$ & $50.50 \pm 9.19^{\mathrm{c}}$ & $16.84 \pm 3.06^{\mathrm{w}}$ \\
IV & $43.00 \pm 4.58^{\mathrm{d}}$ & $14.00 \pm 2.00^{\mathrm{x}}$ & $41.00 \pm 7.55^{\mathrm{d}}$ & $13.67 \pm 2.52^{\mathrm{x}}$ \\
V & $36.50 \pm 4.95^{\mathrm{e}}$ & $12.89 \pm 1.17^{\mathrm{y}}$ & $45.33 \pm 4.16^{\mathrm{e}}$ & $15.11 \pm 1.39^{\mathrm{y}}$ \\
\hline
\end{tabular}

Results are mean \pm standard deviation, Values in the same row bearing similar superscripts are significantly different at $P<0.05$. (n=3). Key: I:

Negative Control Group, II: positive control and III, IV and V: Test groups, FLAE: Fresh Leaf Aqueous Extract.

There were significant differences $(P<0.05)$ observed in comparing group I with groups III, IV and V. Also, significant differences $(P<0.05)$ were observed when the treated groups (III, IV and V) are compared with one another, not necessary in a dose dependent manner. As shown in Figure 1, the results of induction with $200 \mathrm{mg} / \mathrm{kg} \mathrm{CCl}_{4}$ reveal significantly higher $(P<0.05)$ levels of groups II (positive control), III, IV and V compared to group I (negative control).

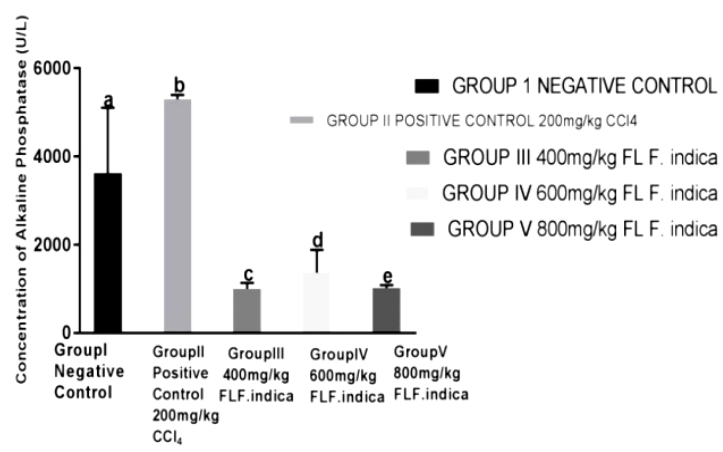

Figure 4: Alkaline phosphatase for $\mathrm{CCl}_{4}$ induced rats treated with fresh leaf aqueous extract of $F$. indica.

FLF. indica $=$ fresh leaf of $F$. indica. Letters a, b, c, d and e indicates significant difference $(P<0.05)$ when group II was compared with groups I, III, IV and V, respectively for $400 \mathrm{mg} / \mathrm{kg}, 600 \mathrm{mg} / \mathrm{kg}$ and $800 \mathrm{mg} / \mathrm{kg} F$. indica treated groups.
Results in Figure 4 also reveal significantly higher $(P<$ $0.05)$ differences in the concentration of Alkaline Phosphatase (ALP) when group I (negative control) is compared with group III (400mg/kg FLF. indica), group IV $(600 \mathrm{mg} / \mathrm{kg}$ FLF indica) and group V $(800 \mathrm{mg} / \mathrm{kg}$ FLF. indica). When the concentrations of ALP in groups III, IV and V were compared with one another, significant differences $(P<0.05)$ were observed in a dose dependent pattern.

\section{DISCUSSION}

Carbon tetrachloride $\left(\mathrm{CCl}_{4}\right)$ induced hepatic injury is shown in Table 1 and (Figure 1 and Figure 3). The rise in the level of ALT, AST, ALB, ALP, BIL and TP of groups II, III, IV and $\mathrm{V}$ when compared to group I indicates a $\mathrm{CCl}_{4}$ induced liver damage. This is consistence with ${ }^{22}$, who reported the use of $1.5 \mathrm{ml} / \mathrm{kg}$ body weight of $\mathrm{CCl}_{4}$ orally administered to rats to induce liver damage. These liver function enzymes are found to be located in the cytosol of the liver cell and thus, are easily released into the serum after cellular liver damage $\mathrm{e}^{23}$. The mechanism of action involved in $\mathrm{CCl}_{4}$ hepatic injury is understood to be linked to the liver phase II detoxification action. The liver, in the process of detoxification transforms Carbon tetrachloride $\left(\mathrm{CCl}_{4}\right)$ in the presence and action of cytochrome $\mathrm{P}_{450}$ enzyme component to produce peroxy trichloromethyl and trichloromethyl free radicals ${ }^{13}$. These free radicals results in lipid peroxidation by 
reacting covalently with biomolecules (proteins, nucleic acids, lipids etc) in the presence of oxygen. Thus the liver becomes damaged and obviously its cell membrane becomes degenerate, permeable and licks out its cellular contents of AST, ALT, TP, ALP, BIL and $\mathrm{ALB}^{24}$

Table 4: Blood Glucose Concentration (mg/dl) of Rats after Induction with $\mathrm{CCl}_{4}$ and after Treatment with FLAE of $F$. indica.

\begin{tabular}{lcc}
\hline Group & $\begin{array}{c}\text { After } \\
\text { Induction }\end{array}$ & $\begin{array}{c}\text { After } \\
\text { Treatment }\end{array}$ \\
\hline I & $100.39 \pm 1.66^{\mathrm{a}}$ & $89.88 \pm 25.71^{\mathrm{a}}$ \\
II & $88.26 \pm 1.19^{\mathrm{b}}$ & $99.93 \pm 2.76^{\mathrm{b}}$ \\
III & $102.33 \pm 1.52^{\mathrm{c}}$ & $95.00 \pm 5.29^{\mathrm{c}}$ \\
IV & $93.33 \pm 4.16^{\mathrm{d}}$ & $80.00 \pm 12.29^{\mathrm{d}}$ \\
V & $82.67 \pm 15.37^{\mathrm{e}}$ & $81.00 \pm 11.14^{\mathrm{e}}$ \\
\hline
\end{tabular}

Results are mean \pm standard deviation, Values in the same row bearing similar superscripts are significantly different at $P<0.05$. $(\mathrm{n}=3)$. Key: I: Negative Control Group, II: positive control and III,

IV and V: Test groups, FLAE: Fresh Leaf Aqueous Extract.

After induction with $\mathrm{CCl}_{4}$, the level of blood glucose was raised (Table 4), hemoglobin and PCV (Table 3) levels were decreased. This could suggest that $\mathrm{CCl}_{4}$ induced anemia was possible owing from the destruction of red blood cells and shortage of circulating mineral iron and vitamins ${ }^{15}$. Hyperglycemia induced by $\mathrm{CCl}_{4}$ could be due pancreatic injury caused by generation of free radical, cell membrane lipid peroxidation and subsequent destruction of pancreatic $\beta$ - islet cells ${ }^{3}$.

Table 5: Body Weight of rats before induction with $\mathrm{CCl}_{4}$, after induction with $\mathrm{CCl}_{4}$ and after treatment with FLAE of $F$. indica.

\begin{tabular}{lccc}
\hline Group & $\begin{array}{c}\text { At } \\
\text { acclimatization }\end{array}$ & $\begin{array}{c}\text { At induction } \\
\text { with } \mathbf{C C l}_{\mathbf{4}}\end{array}$ & $\begin{array}{c}\text { Treatment } \\
\text { with FLAE } \\
\text { of } \boldsymbol{F} \text {. } \text { indica }\end{array}$ \\
\hline I & $184.49 \pm 11.55^{\mathrm{a}}$ & $218.21 \pm 7.70^{\mathrm{a}}$ & $206.45 \pm 16.05^{\mathrm{a}}$ \\
II & $179.10 \pm 13.13^{\mathrm{b}}$ & $221.15 \pm 14.42$ & $207.55 \pm 6.16^{\mathrm{b}}$ \\
III & $222.48 \pm 13.93^{\mathrm{c}}$ & $187.76 \pm 28.90^{\mathrm{c}}$ & $235.10 \pm 34.22^{\mathrm{c}}$ \\
IV & $246.63 \pm 48.53^{\mathrm{d}}$ & $227.95 \pm 41.98^{\mathrm{d}}$ & $241.27 \pm 63.52^{\mathrm{d}}$ \\
V & $227.20 \pm 45.07^{\mathrm{e}}$ & $219.63 \pm 39.17^{\mathrm{e}}$ & $274.43 \pm 38.20^{\mathrm{e}}$ \\
\hline \multicolumn{3}{c}{ Results are mean \pm standard deviation, Values in the same row } \\
bearing similar superscripts are significantly different at P<0.05. \\
(n=3). Key: I: Negative Control Group, II: positive control and III, \\
\multicolumn{3}{c}{ IV and V: Test groups, FLAE: Fresh Leaf Aqueous Extract. }
\end{tabular}

Administration of $\mathrm{CCl}_{4}$ induced rats with FLAE of $F$. indica shows reduction in the concentrations of liver function enzymes (TP, AST, ALT, ALP, and BIL) in the serum and blood glucose (Table 2 and Table 4 and Figure 2 and Figure 4). Similarly, after treatment with FLAE of $F$. indica the levels of ALB, $\mathrm{Hb}$ and PCV increased as shown in Table 2 and Table 4. The reduced serum levels of the liver function enzymes indicate the recuperative, regenerative and healing effect of FLAE of $F$. indica on the hepatic cells. This is in support of a previous $\operatorname{study}^{3}$, who reported that treatment with $F$. indica's ethanol extract stem bark with $500 \mathrm{mg} / \mathrm{kg}$ and $700 \mathrm{mg} / \mathrm{kg}$ in rats liver revealed regeneration of hepatocytes and absence of inflammation. It appears FLAE of $F$. indica exert its effects by antioxidant and free radical scavenging strength by furnishing the body with antioxidants phytochemicals (tannins, flavonoids, carotenoids, anthacyanins), minerals (Fe, $\mathrm{Mg}, \mathrm{Mn}, \mathrm{Na}, \mathrm{K}$ ) and vitamins $(\mathrm{A}, \mathrm{C} \text { and } \mathrm{E})^{\mathbf{4 , 2 2}}$.

Blood glucose was found to decrease with treatment with FLAE of $F$. indica. This could be associated with its antioxidant ability of increasing insulin production and regeneration of the $\beta$ - islet cells of pancreas that was ones destroyed by $\mathrm{CCl}_{4}$ induction ${ }^{22,7}$ buttresses that the presence of minerals in plants enhance effective function of the glycolytic pathway enzymes for the breakdown of glucose. That minerals enhances the phosphorylation conversion reaction of glucose to glucose 6-phosphate by the action of the enzyme hexokinase or glucokinase and phosphorylation of fructose 6-phosphate by the action of phosphofructose kinase (PFK) to fructose 1, 6-bisphosphate ${ }^{7}$. The hematological indices of $\mathrm{PCV}$ and $\mathrm{Hb}$ after treating the $\mathrm{CCl}_{4}$ anemia induced rats with FLAE of $F$. indica revealed increased levels of $\mathrm{PCV}$ and $\mathrm{Hb}$. The antianaemic and haem regenerating effects of FLAE of $F$. indica as depicted by the results of this study, could be associated to some extent on the antioxidants phytochemical and mineral elements it contains ${ }^{14,9}$. Antioxidant phytochemicals such as saponins, flavonoids and alkaloids have been reported for their ant-anemic abilities, prevent thrombosis and aggregation of platelet and promote enhanced blood circulation $^{25,26}$. Thus, FLAE of $F$. indica was able to increase the levels of PCV and $\mathrm{Hb}$ because of these phytochemicals and mineral elements contents. This action could be made possible by its enhanced removal of the toxic effects caused by $\mathrm{CCl}_{4}$ and creating flourishing iron utilization for the production of heme and subsequent release of new red blood cells ${ }^{14}$. FLAE of $F$. indica could have exert its effects in the improved production of $\mathrm{Hb}$ and $\mathrm{PCV}$ by enhancing the production of erythropoietin in the bone marrow stem cells and subsequent synthesis of new blood cells ${ }^{27}$. In addition, there was an observed reduced body weight of anemic rats $\left(\mathrm{CCl}_{4}\right.$ induced groups) when compared to the groups treated with FLAE of $F$. indica (Table $5)$. This reduction in body weight of anemic rats and increase or weight gain in the treated group with FLAE of $F$. indica is consistent with the report of previous study ${ }^{14}$. The association of weight loss with anemia is not very clear. However, it appears to be related to defect in carbohydrates digestion in the small intestine of anemic rats due to insufficient amount of the enzyme, disaccharidases, thus leading to undigested carbohydrates $^{28}$.

\section{CONCLUSION}

The use of fresh leaf aqueous extract of $F$. indica in this study reveals that the plant possesses anti-anemia, hypoglycemic and hepato-healing potentials. This is obviously seen in the reduced levels of blood glucose, liver function assay, and in the raised levels of the hematological parameters, coupled with weight gain after treating $\mathrm{CCl}_{4}$ induced groups with FLAE of $F$. indica.

\section{AUTHOR'S CONTRIBUTION}

All authors have worked equally for this work. 


\section{ACKNOWLEDGEMENTS}

The authors extend their thanks and appreciation to the Caritas University, Nigeria to provide necessary facilities for this work.

\section{CONFLICT OF INTEREST}

Authors have declared that no conflict of interest is linked with this work.

\section{REFERENCES}

1. Eramma N, Devaraja G. Antibacterial potential and phytochemical analysis of Flacourtia indica (Burm.f.) Merr. root extract against human pathogens. Indo American J Pharm Res 2013: 3(5).

2. Ihcène B, Asma B, Amel B, Abdelfattah EF, Mahfoud M. Antioxidant effect of alpha lipoic acid on hepatotoxicity induced by aluminium chloride in rats. Int $\mathrm{J}$ Pharm Sci Rev Res 2014; 29(2): Pages: 19-25. https://doi.org/10.1155/2018/2817036

3. Idokoa A, Emmanuel UG, Yakubu O, Ugwudike P, Patricia N. Hepatocurative and gluco-stabilizing potentials of ethanol extract of stem bark of flacourtia indica in aluminium chloride induced toxicity in albino wistar rats. Curr Trends Biomedical Eng Biosci 2018; 17(3): 1-7. DOI: $10.19080 / C T B E B .2018 .17 .555965$. https://doi.org/10.1155/2018/2817036

4. Ammar A, Naoufal L, Azam B, Dennis G. Watson and David A. Lightfoot. Phytochemicals extraction, isolation, and identification of bioactive compounds from plant extracts. Plants 2017; 6(42): 1-23.

https://doi.org/10.3390/plants6040042

5. Vivekananthan DP, Penn MS, Sapp SK, Hsu A, Topol EJ. Use of antioxidant Vitamins for the prevention of Cardiovascular diseases. Meta-analysis of Randomized trials. Lancet 2003; 361: 2017-2023. https://doi.org/10.1016/S0140-6736(03)13637-9

6. Abubakar SM, Umar SA, Alexander I, Abubakar N, Abdulazeez MA, Sule MS. Evaluation of hypoglycaemic, hypolipidaemic and non toxic effect of hydro-methanolic extracts of Ziziphus mauritiana, Ziziphus spina christi fruit and glibenclamide on alloxan induced diabetic rats. J Drug Deliv Therap 2018; 8(3): 82-92. https://doi.org/10.22270/jddt.v8i3.1711

7. Idoko A, Ikpe VPO, Rita ON, Nelson NO, Effiong JU, Alhassan AJ, Muhammed IU, Abubakar N, Abubakar SM, Ugwudike PO. Hypoglycemic and lipid profile lowering effect of chromolaena odorata (linn) in albino wistar rats fed different concentrations of cholesterol enriched diet. Univ J Pharm Res 2018; 3(1): 37-42. https://doi.org/10.22270/ujpr.v3i1.R7

8. Idoko A, Ikpe VPO, Nelson NO, Effiong JU, Alhassan AJ, Muhammad IU, Abubakar, N, Abubakar SM. Effects of Lime Juice and Honey on Lipid Profile of Cholesterol Enriched Diet Fed Rat Model. Annual Res Rev Biol 2017; 20(3): 1-10. https://doi.org/10.9734/ARRB/2017/37213

9. Abhishek M, Thangadurai D, Shivanand B, Sangeetha J. Proximate analysis and mineral composition of potential minor fruits of Western Ghats of India. Agronomy 2017; Series A. Vol. LX: 340-346.

10. Alan F. An overview of the liver: A series of fact sheets written in the field of liver disease, Hepatitis C Support Project (HCSP publication); 2015 version 1; 1-5. Reviewed January 2018.

11. Tarasankar M, Surajit M, Nilanjan P, Durgesh RK, Subarna G. A review on hepatic diseases and development of herbal drugs for the treatment of liver complications. World J Pharm Res 2015; 4(6): 677-691.
12. Gupta AK, Ganguly P, Majumder UK, Ghosal S. Hepatoprotective and antioxidant effect and stereoidal saponins of solanum of Solanum xanthocarpum and Solanum nigrum in paracetomol induce hepatotoxicity in rats. Pharmacologyonline 2009; 1: 757-768.

13. Weber LW, Boll M, Stampfl A. Hepatotoxicity and mechanism of action of haloalkanes: carbon tetrachloride as a toxicological model. Crit Rev Toxicol 2003; 33: 10536. https://doi.org/10.1080/713611034

14. Luka CD, Abdulkarim M, Adoga GI, Tijjani H, Olatunde A. Anti-anaemic potential of aqueous extract of spinacia oleracea leaf in phenylhydrazine-treated rats. New York Sci J 2014; 7(6): 14-18.

15. Hoffman R, Edward B, Leslie S, Helen H, Jeffrey W, John Anastasi. Hematologic aspects of parasitic diseases. In: Hematology: Basic Principles and Practice. $6^{\text {th }}$ ed. Philadelphia, Pa.: Saunders Elsevier; 2012. http://www.elsevier.com. Accessed January 17, 2019.

16. Khoo SB. Haematinics for Anaemia in the Elderly. Malaysian Fam Phys 2011; 6(1):1-8.

17. Zimmerman M. Ethical guidelines for investigations of experimental pain in conscious animals. Pain 1995; 16(2): 109-11. https://doi.org/10.1016/0304-3959(83)90201-4

18. National Institute of Health. Guidelines for the care and use of laboratory animals, National Academic Press, 1937; 85-23.

19. Mauro P, Renze B, Wouter W. In: Tietz text book of clinical chemistry and molecular diagnostics. $4^{\text {th }}$ edition. Carl AB, Edward R, David EB, editors. Elsevier; Enzymes. 2006; 604-616. https://doi.org/10.1007/s12291-012-0287-7

20. Barbara JB, Imelda B. Basic haematologic techniques. In: Lewis SM, Bain BJ, Bates I, editors. Dacie and Lewis Practical Haematology. $11^{\text {th }}$ ed. London: Churchill Livingston; 2001; 19-46. https://doi.org/10.1016/B0-443-06660-4/X5001-6

21. Graphpad Instat3 and graphpad prism Softwares. 2000. Available: www.graphpad.com. Retrieved on $24^{\text {th }}$ November, 2018.

22. Anindita B, Gangarao B. Flacourtia indica (burm.f.) prevents ccl4 induced rat liver damage by augmenting antioxidant enzyme activity. Eur J Pharm Med Res 2016; 3(4): 263-270.

23. Bagban IM, Roy SP, Chaudhary A, Das SK, Gohil KJ, Bhandari KK. Hepatoprotective activity of the methanolic extract of Fagonia indica Burm in carbon tetra chloride induced hepatotoxicity in albino rats. Asian Pacific J Trop Biomed 2012; 1457-1460.

https://doi.org/10.1016/S2221-1691(12)60437-7

24. Recknagel RO, Glende EA, Dolak JA, Waller RL. Mechanisms of carbon tetrachloride toxicity. Pharmacol Ther 1989; 43: 139-154. https://doi.org/10.1016/01637258(89)90050-8

25. Shi J, Arunasalam K, Yeung D, Kakuda Y, Mittal G, Jiang Y. Saponins from edible legumes: chemistry, processing, and health benefits. J Med Food 2004; 7: 67-78. https://doi.org/10.1089/109662004322984734

26. Falcone A, Musto P, Rasario P, Rosella M. Compounds and Methods for treatment of chemotherapy-induced Anemia. Europ J Haemat 1997; 58:34 -319.

27. Ganong WF. A review of medical physiology appleton and Lange Pubiisher. 1997:96.

28. Vieira MR, Galzvao LC, Fernandes MIM. Relation of the disaccharidases in the small intestine of the rat to the degree of experimentally induced iron-deficiency anaemia. Braz J Med Biol Res 2000; 33: 539-544. 